Case Closed 



\title{
Case Closed
}

\section{Holocaust SuRVIVORS IN POSTWAR AMERICA}

\author{
BETH B. COHEN
}

Rutgers University Press

New Brunswick, New Jersey, and London

Published in association with the United States

Holocaust Memorial Museum 


\section{Library of Congress Cataloging-in-Publication Data}

Cohen, Beth B., 1950-

Case closed: Holocaust survivors in postwar America / Beth B. Cohen.

p. $\mathrm{cm}$.

Includes bibliographical references and index.

ISBN-13: 978-0-8135-3953-9 (hardcover : alk. paper)

1. Jews-United States-History-20th century. 2. Holocaust survivors-United

States-History - 20th century. 3. Jews, European-United States-History-20th century. 4. Refugees, Jewish-United States-History-20th century.

5. Immigrants-United States-History-20th century. I. Title.

E184.355.C63 2007

$304.8 ' 73008992404-\mathrm{dc} 22$

2006011618

A British Cataloging-in-Publication record for this book is available from the British Library.

The assertions, arguments, and conclusions contained herein are those of the author or other contributors. They do not necessarily reflect the opinions of the United States Holocaust Memorial Museum.

Copyright (C) 2007 by Beth B. Cohen

All rights reserved

No part of this book may be reproduced or utilized in any form or by any means, electronic or mechanical, or by any information storage and retrieval system, without written permission from the publisher. Please contact Rutgers University Press, 100 Joyce Kilmer Avenue, Piscataway, NJ 08854-8099. The only exception to this prohibition is "fair use" as defined by U.S. copyright law.

Manufactured in the United States of America 
To Steve 
